\title{
Early-Middle Permian palynoflora of Shandong Province, eastern North China
}

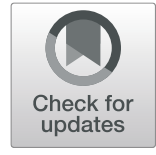

Tian-Tao Yin ${ }^{1,2}$, Shou-Jun Li ${ }^{*}$ (D), Xiang-Yu Zhang ${ }^{1}$ and Xiu-Li Zhao ${ }^{1}$

\begin{abstract}
The Permian Taiyuan and Shanxi formations exposed in Shandong Province, eastern North China, contain abundant spores and pollen. In this study, a total of 42 genera and 146 species of spores and pollen from these Permian formations, native to northern China, are identified and related to the three epochs of the Permian Period (Cisuralian, Guadalupian, and Lopingian Epochs) as two assemblages: Assemblage 1 - the LaevigatosporitesGranulatisporites assemblage, inferred as the Cisuralian ( 298.9-272.9 Ma); and, Assemblage II - the GulisporitesSinulatisporites assemblage, inferred as the Guadalupian ( 272.9-259.1 Ma). Assemblage I represents growing ferns, whereas Assemblage II represents gymnosperms. The assemblage division and analysis indicated that the palaeoclimate of the study area during Early-Middle Permian time was dominated by warm and humid conditions, and later in the Middle Permian changed into moderately dry conditions.
\end{abstract}

Keywords: Permian, Spores and pollen, Vegetation succession, Paleoclimate, Environmental change, Taiyuan Formation, Shanxi Formation

\section{Introduction}

In recent decades, Carboniferous to Permian floras of China have been studied by many scientists (Gao 1984; Cheng 2000; Shi and Chen 2003; Hilton and Cleal 2007; Wang 2010; Spencer et al. 2013), and global terrestrial vegetation has also been widely studied (Phillips and DiMichele 1992; Peppers 1996; Cleal and Wang 2002; DiMichele et al. 2006, 2009, 2011). The evolution of plants during the Carboniferous and Permian Periods is commonly ascribed to their development, climatic zoning, and environmental change. Four distinct floras developed worldwide during the Pennsylvanian-Cisuralian Epochs were recognized respectively as the Cathaysian flora, the Euramerican flora, the Angaran flora, and the Gondwanan flora (Sun 1997; DiMichele et al. 2001; Hilton and Cleal 2007). These floras evolved under dissimilar environmental conditions. The Gondwanan and Angaran floras, different from the Euramerican and Cathaysian floras of low palaeolatitude and tropical area,

\footnotetext{
* Correspondence: lishoujun@126.com

${ }^{1}$ College of Earth Science and Engineering, Shandong University of Science and Technology, Qingdao 266590, Shandong Province, China

Full list of author information is available at the end of the article
}

were prevalent in middle and high palaeolatitudes (Meyen 1997; Vega and Archangelsky 1997; DiMichele et al. 2001; Naugolnykh 2002; Hilton and Cleal 2007).

Despite their location in low palaeolatitudes, research on the Euramerican and Cathaysian floras indicated some distinctions between the two floras. Sun $(1996,2001)$ discovered that the Cathaysian flora evolved from the Mississippian "global" Lepidodendropis flora. In addition, it is different from the Euramerican flora with the characteristics of endemic genera and species such as Cathysiodendron, Gigantopteris, Gigantonoclea, Cathaysiopteris, etc. (Sun 2006). Wang and Pfefferkorn (2013) also supported this viewpoint, suggesting that the Cathaysia flora has its own genera and species, which are different from the Euramerican flora. Furthermore, Hilton and Cleal (2007) inferred that the extinction time of the ecosystems of Euramerican and Cathaysia floras were inconsistent, which might be caused by climatic and environmental changes. Therefore further analysis is needed to improve understanding of the distinctions between Euramerican and Cathaysian floras.

Evolution of the Permian floras in China has been investigated in numerous researches regarding plant fossil 
assemblages (e.g., Tian et al. 1996, 2000; Sun 2001; Cleal and Wang 2002; Hilton and Cleal 2007; Wang 2010; DiMichele et al. 2011), such as the Cathaysian tropical flora reported in North China (Li 1997; Ouyang and Hou 1999; Hilton and Cleal 2007), the Cisuralian coalforming flora originated from the Wuda District of Inner Mongolia (Pfefferkorn and Wang 2007), and, the macrofloral assemblages from Weibei coalfield of North China (Wang 2010); these previous researches provide a basis for this study.

Permian stratigraphy in South China was divided into three epochs based on marine setting data (Shen et al. 2005; Zhang et al. 2009), through comparisons of conodont-bearing stratigraphic sections with those in other areas of the world (Mei et al. 2004; Shen and Mei 2010; Shen et al. 2019). In contrast, the Permian strata in North China were continental and lacked international correlatives for comparison.

Shandong Province of eastern North China deposited a large number of coal resources during the CarboniferousPermian. There were abundant spores and pollen in these sediments. A number of studies have been conducted on the Permian palynological fossils in different areas of
Shandong Province, including the Jining coalfield (Ouyang and Hou 1999), Xinwen coalfield (Song et al. 2005), Yanzhou coalfield (Zhu et al. 2005), Tengxian coalfield (Su et al. 2007), and Echeng coalfield (Song et al. 2009). However, these studies used the older stratigraphy of the twofold division scheme of the Lower and Upper Permian.

In contrast to the foregoing studies, this study puts forward some innovative results of the Permian palynological fossils in Shandong Province based on the current three-fold division of the Permian System. The aim of this study is to develop a more detailed understanding of Permian paleontology and stratigraphy in the study area and to provide evidence for the boundary identification between the Lower and Middle Permian in North China.

\section{Geological setting}

Shandong Province is located in the east of the North China Block (NCB; Fig. 1a), which is about $320 \mathrm{~km}$ from north to south and $280 \mathrm{~km}$ from east to west (Fig. 1b). Our study area is bounded by the Liaocheng-Lankao Fault in the west, Qihe-Guangrao Fault in the north,

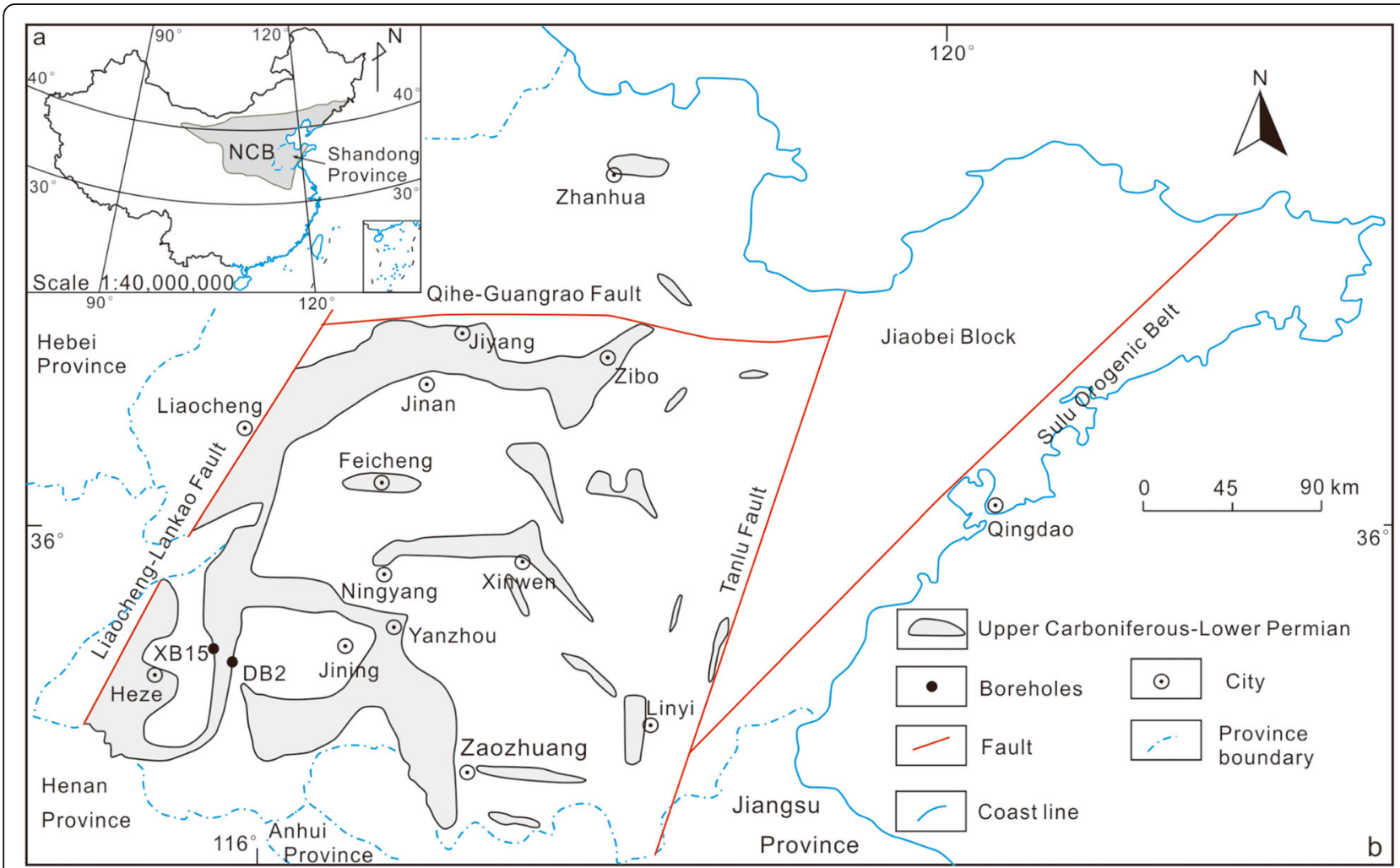

Fig. 1 a Location of the Shandong Province in North China (the map of China is based on the standard map available on the official website of Ministry of Natural Resources of China: http://bzdt.ch.mnr.gov.cn/); b The Upper Carboniferous to Lower Permian strata distribution in Shandong Province and locations of the studied boreholes (XB15 and DB2) 
Tanlu Fault in the east (Fig. 1b). The two boreholes (XB15 and DB2) selected in this study are located in the Heze area of Shandong Province.

Upper Carboniferous to Lower Permian strata in Shandong Province are composed mainly of the Taiyuan and Shanxi formations in ascending order (Fig. 2). The Taiyuan Formation consists mostly of limestone, mudstone, sandstone and coal seams. The Shanxi Formation is characterized by thick sandstone, silty mudstone, and a small amount of coal. The upper Taiyuan Formation is of the marine/continental setting, and the Shanxi Formation indicates a continental environment.
Research on the Cathaysian flora has a long history. The term "Cathaysian flora" was proposed by Halle (1935) and is derived from the ancient microcontinent Cathaysia that constituted the easternmost part of Pangea. The Pennsylvanian to Permian Cathaysian flora contains true ferns, seed ferns, sphenopsids, and other plants (Sun 1996; Zhao et al. 2006; Yin et al. 2016), indicating tropical rainforest conditions. This flora was prevalent in areas corresponding to present-day Asia, including China, Korea, Japan, and other low-latitude countries. Additionally Li (1997) established two floras

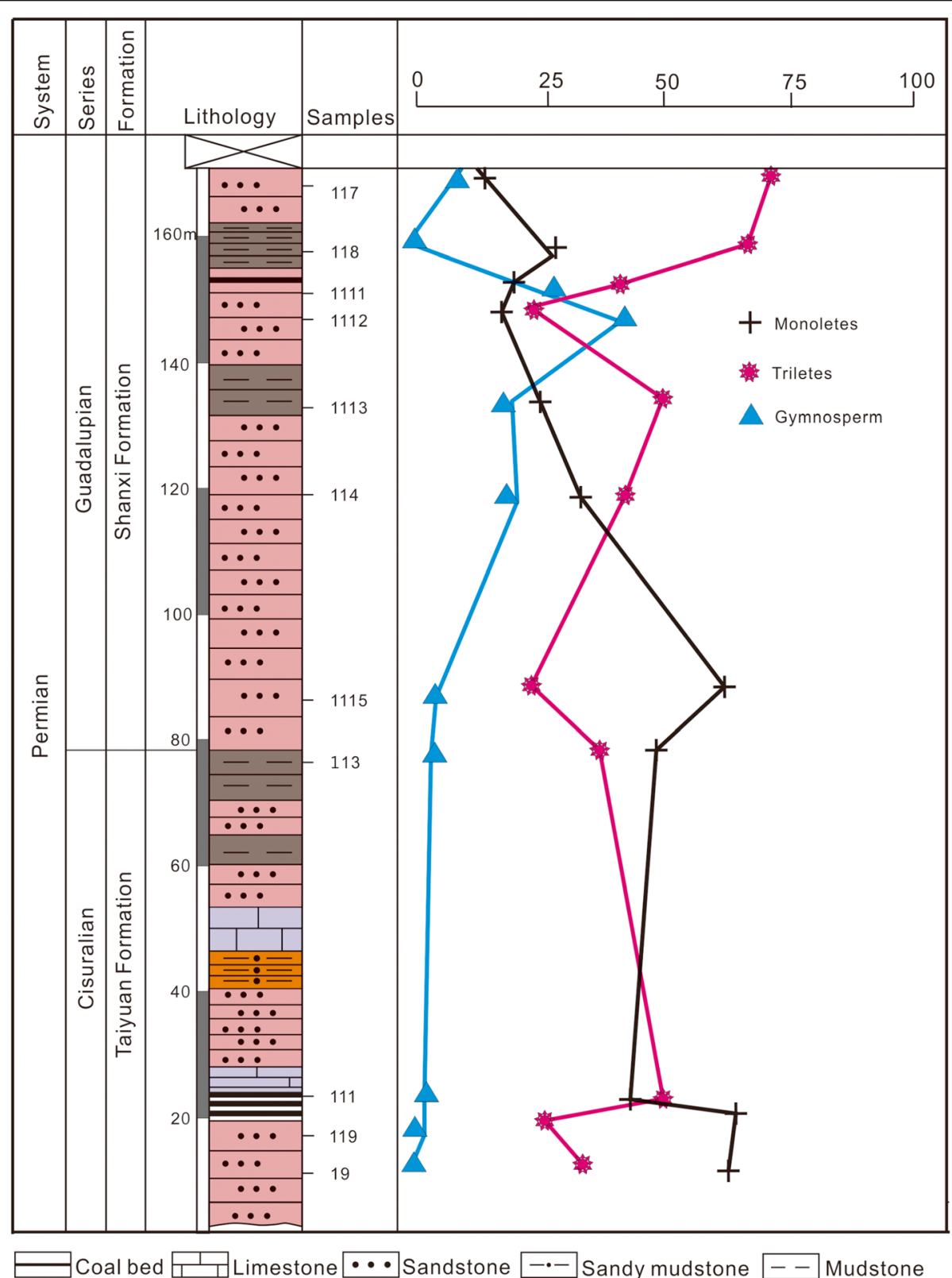

Fig. 2 The major stratigraphy, lithology, and fossil contents/variations of the Permian in Shandong Province, eastern North China (modified after Lü 2015) 
in the Taiyuan and Shanxi formations in North China, namely, Neuropteris ovata-Lepidodendron posthumii and Emplectopteridium alatum-Taeniopteris mucronata-Lobatannularia sinensis plant assemblages, both belonging to the Cathaysian flora.

The Euramerican flora also attracted the interest of many scholars. Two main biomes are recognized in Europe and America continents in wetlands and seasonally dry environments during the Pennsylvanian to Permian (e.g., DiMichele and Aronson 1992; Falcon-Lang and Scott 2000). The wetland biomes are the best known and can be broadly subdivided into peat-forming-swamp and flood-basin floras (e.g., Gastaldo 1987; Gastaldo et al. 1996). Evidence for seasonally-dry communities is indicated by the presence of conifers during Middle Pennsylvanian (Scott 1974). Until the latest Carboniferous (of the older-named Stephanian Epoch), both the peat-forming-swamp and flood-basin floras occurred as well-developed, mainly seed-plantdominated assemblages (Winston 1983; DiMichele and Aronson 1992; DiMichele et al. 2001).

In recent years, some Chinese scholars conducted extensive research on Permian palynological fossils in Shandong Province (e.g., Ouyang and Hou 1999; Jiang et al. 2002; Song et al. 2005, 2009; Su et al. 2007). They established different spore and pollen assemblages in the Taiyuan and Shanxi formations and discussed their characteristics and geological age. But these studies were based mainly on the traditional two-fold division scheme of the Permian (Lower and Upper). After division of Permian strata into three series/epochs (i.e., the Lower/Early, Middle/Middle, and Upper/Late Permian), $\mathrm{Li}$ et al. (2013) established two spore and pollen assemblages in the Taiyuan and Shanxi formations of Pengzhuang coalfield, discussed their characteristics and tried to solve the problem of their age attribution. However, the affinities of spores and pollen need further studies.

This study is based on analyses in relation to the three series/epochs of Permian in eastern North China and investigation of spores and pollen within the two studied boreholes. It attempts to explain the affinities of spores and pollen, discuss the palaeoclimate reflected by them, and compare them with the Euramerican flora. This study is significant to understand the characteristics of the Early-Middle Permian flora in Shandong Province, to enrich the Late Paleozoic flora in North China, and to further rectify the boundary of the Permian internal series in North China Block.

\section{Material and methods}

Eleven core samples were collected from each of the two studied boreholes (XB15 and DB2). Sediments most likely to yield palynomorphs (e.g., silt) were preferentially sampled. All of the samples contained abundant spore and pollen fossils. In the Spore and Pollen Laboratory of Shandong University of Science and Technology,
Qingdao, sludge on the sample surface was removed and then clean samples were crushed for sieving with 0.3 $\mathrm{mm}$ pore diameter. After drying, $30 \mathrm{~g}$ of dried sediment from each sample was weighed and placed in a $1000 \mathrm{ml}$ beaker, to which heavy liquid comprising hydrochloric acid, hydrofluoric acid, hydroiodic acid, and potassium iodide was added to macerate, fully dispersing the sample in the solvent and allowing organic material to be separated. Samples were repeatedly washed with tap water for about 2 weeks and the water was changed every 8 hours day by day. Sieve residues were dried to

Table 1 Authoritative name and corresponding representative illustration of Assemblage I taxa identified from the Permian spore and pollen fossils of boreholes XB15 and DB2 in Shandong Province

\begin{tabular}{|c|c|c|}
\hline Taxa & Literature & Illustration \\
\hline Calamospora breviradiata & Kosanke 1950 & Fig. 3a \\
\hline Calamospora sp. & Schopf et al. 1944 & Fig. 3b \\
\hline Calamospora hartungiana & Gao 1984 & Fig. $3 c$ \\
\hline Calamospora minuta & Bharadwaj 1957 & Fig. 3d \\
\hline Convolutispora cerebra & Smith and Butterworth 1967 & Fig. $3 e$ \\
\hline Convolutispora tessellata & Hoffmeister et al. 1955 & Fig. $3 f$ \\
\hline Crassispora adornata & Ouyang 1962 & Fig. $3 g$ \\
\hline Cyclogranisporites aureus & Potonié and Kremp 1955 & Fig. 3h \\
\hline Cyclogranisporites micaceus & Imgrund 1952 & Fig. 3i \\
\hline Densosporites annulatus & Smith and Butterworth 1967 & Fig. $3 j$ \\
\hline Florinites minutus & Bharadwaj 1954 & Fig. 3k \\
\hline Foveolatisporites junior & Bharadwaj 1957 & Fig. 31 \\
\hline Granulatisporites minutus & Potonié and Kremp 1955 & Fig. $3 m$ \\
\hline Gulisporites cereris & Gao 1984 & Fig. $3 n$ \\
\hline Gulisporites cochlearius & Imgrund 1960 & Fig. 30 \\
\hline Laevigatosporites minimus & Schopf et al. 1944 & Fig. $3 p$ \\
\hline Laevigatosporites maximus & Potonié and Kremp 1956 & Fig. 4a \\
\hline Laevigatosporites vulgaris & Ibrahim 1933 & Fig. $4 b$ \\
\hline Laevigatosporites perminutus & Alpern 1958 & Fig. $4 c$ \\
\hline Leiotriletes adnatus & Potonié and Kremp 1955 & Fig. 4d \\
\hline Leiotriletes sphaerotriangulus & Potonié and Kremp 1954 & Fig. $4 \mathrm{e}$ \\
\hline Leiotriletes sp. & Potonié and Kremp 1954 & Fig. $4 f$ \\
\hline Lycospora pusilla & Schopf et al. 1944 & Fig. $4 \mathrm{~g}$ \\
\hline Microreticulatisporites sp. & Potonié and Kremp 1954 & Fig. $4 \mathrm{~h}$ \\
\hline Punctatisporites sp. & Potonié and Kremp 1954 & Fig. $4 \mathrm{i}$ \\
\hline Punctatosporites granifer & Potonié and Kremp 1956 & Fig. $4 \mathrm{j}$ \\
\hline Punctatosporites minutus & Ibrahim 1933 & Fig. 4k \\
\hline Striolatospora sp. & Zhou 1980 & Fig. 41 \\
\hline Spinosporites spinosus & Alpern 1956 & Fig. $4 \mathrm{~m}$ \\
\hline Thymospora pseudothiessenii & Kosanke 1950 & Fig. $4 n$ \\
\hline Verrucosisporites verrucosus & Ibrahim 1933 & Fig. 40 \\
\hline
\end{tabular}


make specimens with glycerol. A Nikon microscope and camera were used for microexamination and imaging. All the imaged specimens are housed in the School of Earth Sciences and Engineering, Shandong University of Science and Technology. The grains shown in the plates were located with an England Finder, and the coordinates are held in the same facility as where the specimens are housed.

\section{Results}

A total of 42 genera and 146 species were identified from spore and pollen fossils in sediment samples from the boreholes XB15 and DB2. According to content changes in the spore and pollen fossils (Fig. 2), two assemblages were recognized: Assemblage I, Laevigatosporites-Granulatisporites assemblage; and Assemblage
II, Gulisporites-Sinulatisporites assemblage. The authoritative names and corresponding representative images of Assemblage I taxa are listed in Table 1, and those of Assemblage II taxa are listed in Table 2. In addition, there are other less abundant genera and species that were identified. We speculate that they likely migrated to the study area with rare spores and low content by means of external forces, which are not representative and meaningless to indicate the palaeoclimate of the study area. Therefore, the focus of this study is to discuss the palaeoclimate change reflected by the dominant genera and species in the studied spore and pollen assemblages, which may be more typical.

Prior to the palynology analysis, species data were transformed to relative abundances (percentage) of the

Table 2 Authoritative name and corresponding representative illustration of Assemblage II taxa identified from the Permian spore and pollen fossils of boreholes XB15 and DB2 in Shandong Province

\begin{tabular}{|c|c|c|}
\hline Taxa & Literature & Illustration \\
\hline Calamospora pedata & Kosanke 1950 & Fig. $5 a$ \\
\hline Converrucosisporites minutus & Gao 1984 & Fig. 5b \\
\hline Converrucosisporites sp. & Potonié and Kremp 1954 & Fig. $5 c$ \\
\hline Cyclogranisporites aureus & Potonié and Kremp 1955 & Fig. 3h \\
\hline Cyclogranisporites micaceus & Potonié and Kremp 1955 & Fig. $3 i$ \\
\hline Cyclogranisporites microgranus & Bharadwaj 1954 & Fig. $5 d$ \\
\hline Cyclogranisporites pseudozonatus & Ouyang 1986 & Fig. $5 \mathrm{e}$ \\
\hline Densosporites annulatus & Smith and Butterworth 1967 & Fig. $3 j$ \\
\hline Florinites antiquus & Schopf et al. 1944 & Fig. $5 f$ \\
\hline Florinites minutus & Bharadwaj 1954 & Fig. 3k \\
\hline Gulisporites cereris & Gao 1984 & Fig. $3 n$ \\
\hline Gulisporites cerevus & Imgrund 1960 & Fig. $5 g$ \\
\hline Gulisporites cochlearius & Imgrund 1960 & Fig. 30 \\
\hline Gulisporites curvatus & Gao 1984 & Fig. 5h \\
\hline Gulisporites laevigatus & Imgrund 1960 & Fig. $5 i$ \\
\hline Gulisporites sp. & Imgrund 1960 & Fig. 6a \\
\hline Laevigatosporites minimus & Schopf et al. 1944 & Fig. $3 p$ \\
\hline Leiotriletes adnatus & Potonié and Kremp 1955 & Fig. $4 d$ \\
\hline Leiotriletes sphaerotriangulus & Potonié and Kremp 1954 & Fig. $4 \mathrm{e}$ \\
\hline Leiotriletes tangyiensis & Zhou 1980 & Fig. $6 b$ \\
\hline Lophotriletes cf. communis & Naumova 1953 & Fig. $6 c$ \\
\hline Lophotriletes humilus & Hou and Wang 1986 & Fig. 6d \\
\hline Lycospora pusilla & Schopf et al. 1944 & Fig. $4 \mathrm{~g}$ \\
\hline Punctatisporites gigantus & Ouyang 1986 & Fig. $6 e$ \\
\hline Punctatisporites incomptus & Felix and Burbridge 1967 & Fig. $6 f$ \\
\hline Sinulatisporites of. shanxiensis & Gao 1984 & Fig. $6 \mathrm{~g}$ \\
\hline Sinulatisporites of. sinensis & Gao 1984 & Fig. $6 \mathrm{~h}$ \\
\hline Stenozonotriletes marginellus & Gao 1984 & Fig. $6 i$ \\
\hline Stenozonotriletes sp. & Hacquebard 1957 & Fig. $6 \mathrm{j}$ \\
\hline Triquitrites sp. & Potonié and Kremp 1954 & Fig. $6 \mathrm{k}$ \\
\hline
\end{tabular}


total spore and pollen fossils in the established assemblages; and the spore and pollen fossil content variations were shown in Fig. 2. Diversities of the identified spore and pollen assemblages are illustrated as photomicrographs in Figs. 3, 4, 5 and 6.

\subsection{Characteristics of Assemblage I}

Relative abundance of major taxa in Assemblage I, the Laevigatosporites-Granulatisporites assemblage, identified in the Permian Taiyuan Formation, are provided in Table 3. The main genera and species of monolete spores are Spinosporites spinosus, Laevigatosporites minimus, L. maximus, L. vulgaris, L. perminutus, Thymospora pseudothiessenii, Punctatosporites granifer, P. minutus, and Striolatospora sp.

The main genera and species of Azonotriletes are Granulatisporites minutus, Calamospora breviradiata, C. minuta, C. glaber, C. hartungiana, Verrucosisporites verrucosus, Cyclogranisporites micaceus, Leiotriletes sphaerotriangulus, L. adnatus, L. tangyiensis, Raistrickia saetosa, Cyclogranisporites microgranus, C. aureus, Convolutispora cerebra, C. tessellata, Crassispora adornata, Foveolatisporites junior, and Microreticulatisporites sp. The Zonotriletes mainly include Densosporites annulatus, Gulisporites cereris, G. cochlearius, and Lycospora pusilla.

Gymnosperm pollen is principally Florinites minutus.

\subsection{Characteristics of Assemblage II}

Relative abundance of major taxa in Assemblage II, the Gulisporites-Sinulatisporites assemblage, identified in the Permian Shanxi Formation of Shandong Province, are reported in Table 4.

Azonotriletes include Cyclogranisporites aureus, $C$. micaceus, C. microgranus, Converrucosisporites minutus, C. sp., Punctatisporites incomptus, P. gigantus, Leiotriletes tangyiensis, L. sphaerotriangulus, L. adnatus, Verrucosisporites kaipingiensis, Crassispora mucronata, Calamospora pedata, Lophotriletes cf. communis, and $L$. humilus.
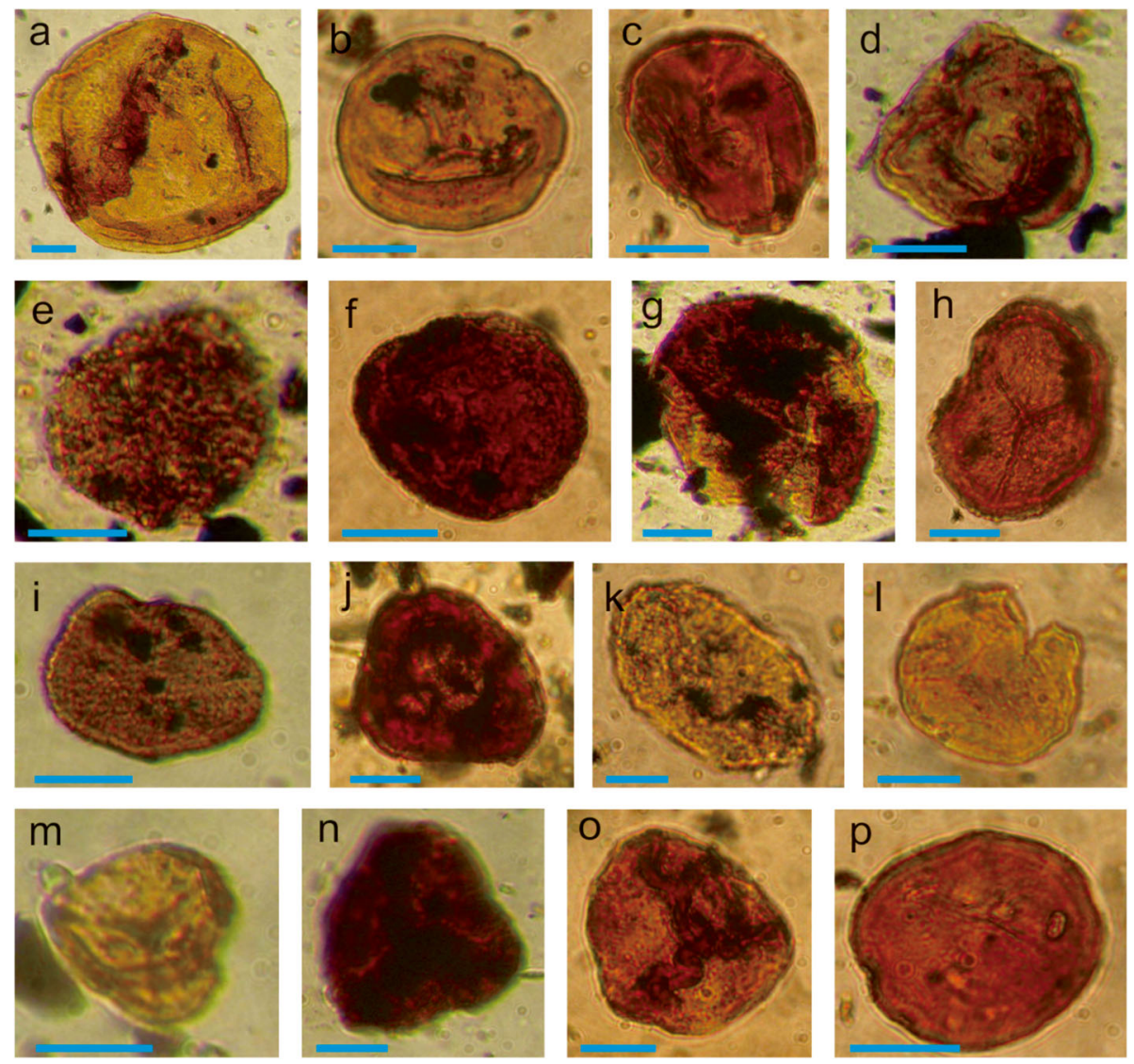

Fig. 3 Photomicrographs of a selection of spore and pollen fossils identified in samples from boreholes XB15 and DB2 in Shandong Province. a Calamospora breviradiata; b Calamospora sp.; c Calamospora hartungiana; d Calamospora minuta; e Convolutispora cerebra; $\mathbf{f}$ Convolutispora tessellata; $\mathbf{g}$ Crassispora adornata; $\mathbf{h}$ Cyclogranisporites aureus; $\mathbf{i}$ Cyclogranisporites micaceus; $\mathbf{j}$ Densosporites annulatus; $\mathbf{k}$ Florinites minutus; I Foveolatisporites junior; $\mathbf{m}$ Granulatisporites minutus; $\mathbf{n}$ Gulisporites cereris; o Gulisporites cochlearius; $\mathbf{p}$ Laevigatosporites minimus. Scale bars (in each) $=20 \mu \mathrm{m}$ 

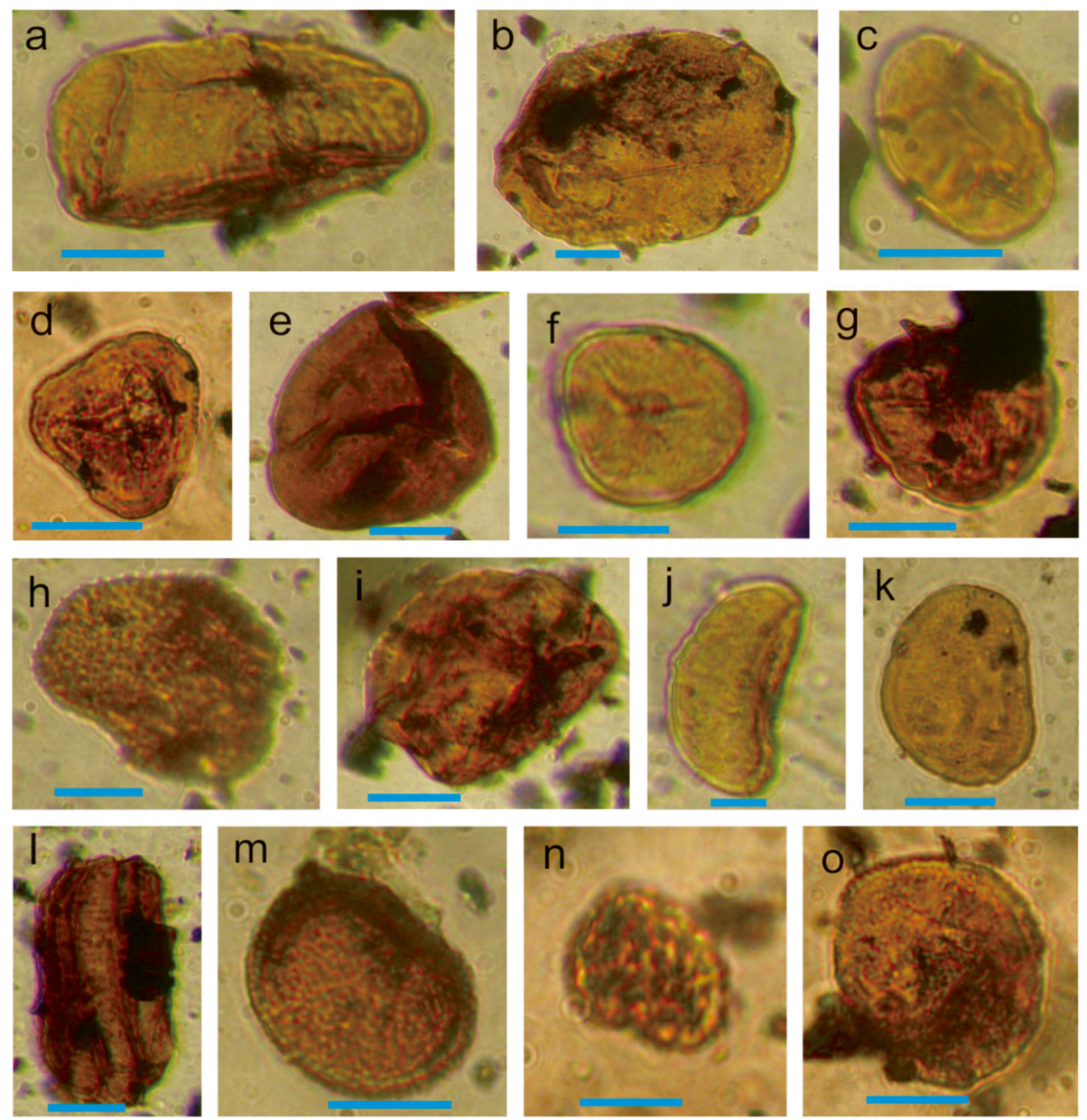

Fig. 4 Photomicrographs of a selection of spore and pollen fossils identified in samples from boreholes XB15 and DB2 in Shandong Province. a Laevigatosporites maximus; b Laevigatosporites vulgaris; c Laevigatosporites perminutus; $\mathbf{d}$ Leiotriletes adnatus; e Leiotriletes sphaerotriangulus; $\mathbf{f}$ Leiotriletes sp.; $\mathbf{g}$ Lycospora pusilla; $\mathbf{h}$ Microreticulatisporites sp.; i Punctatisporites sp.; $\mathbf{j}$ Punctatosporites granifer; $\mathbf{k}$ Punctatosporites minutus; I Striolatospora sp.; $\mathbf{m}$ Spinosporites spinosus; $\mathbf{n}$ Thymospora pseudothiessenii; $\mathbf{o}$ Verrucosisporites verrucosus. Scale bars (in $\mathbf{a}-\mathbf{e}, \mathbf{g}-\mathbf{i}$ and $\mathbf{k}-\mathbf{o}$ ) $=20 \mu \mathrm{m}$; Scale bars (in $\mathbf{f}$ and $\mathbf{j})=10 \mu \mathrm{m}$

Zonotriletes include Gulisporites cochlearius, G. cereris, G. laevigatus, G. cerevus, G. curvatus, G. sp., Sinulatisporites cf. shanxiensis, S. cf. sinensis, Stenozonotriletes marginellus, S. sp., Densosporites anulatus, and Lycospora pusilla.

Monoletes include Punctatosporites minutus and Laevigatosporites minimus.

The principal species of gymnosperm pollen are Florinites antiquus and F. minutus.

\subsection{Difference between Assemblage I and Assemblage II} In Assemblage I (the Laevigatosporites-Granulatisporites assemblage), the genera representing Calamitales (Calamospora), Filicanae (Punctatisporites, Leiotriletes, Granulatisporites) and Sphenopsida (Laevigatoporites) are relatively significant, while the gymnosperms (Florinites) are relatively limited.
In Assemblage II (the Gulisporites-Sinulatisporites assemblage), the genera representing Lycopsida (Crassispora, Densosporites) are scarce, which indicates that the Lycopsida content has shown signs of decline while the gymnosperm content increased in this assemblage compared with Assemblage I. This result proves the further prosperity of Cordaitales.

By comparing the two assemblages, we identified the genera and species that first appeared in Assemblage II or increased significantly compared with Assemblage I include Gulisporites cereris, G. laevigatus, Sinulatisporites cf. sinensis, Stenozonotriletes marginellus, Punctatisporites incomptus, Florinites antiquus, F. minutus, Triquitrites sp., Cyclogranisporites pseudozonatus, C. micaceus, and Lycospora pusilla. Note that abundant Sinulatisporites were found in Assemblage II. This genus has a wide geographical distribution, as well as a stable stratigraphic distribution, mainly in the Shanxi Formation (Ouyang and Hou 1999; Zhang et al. 2005). 

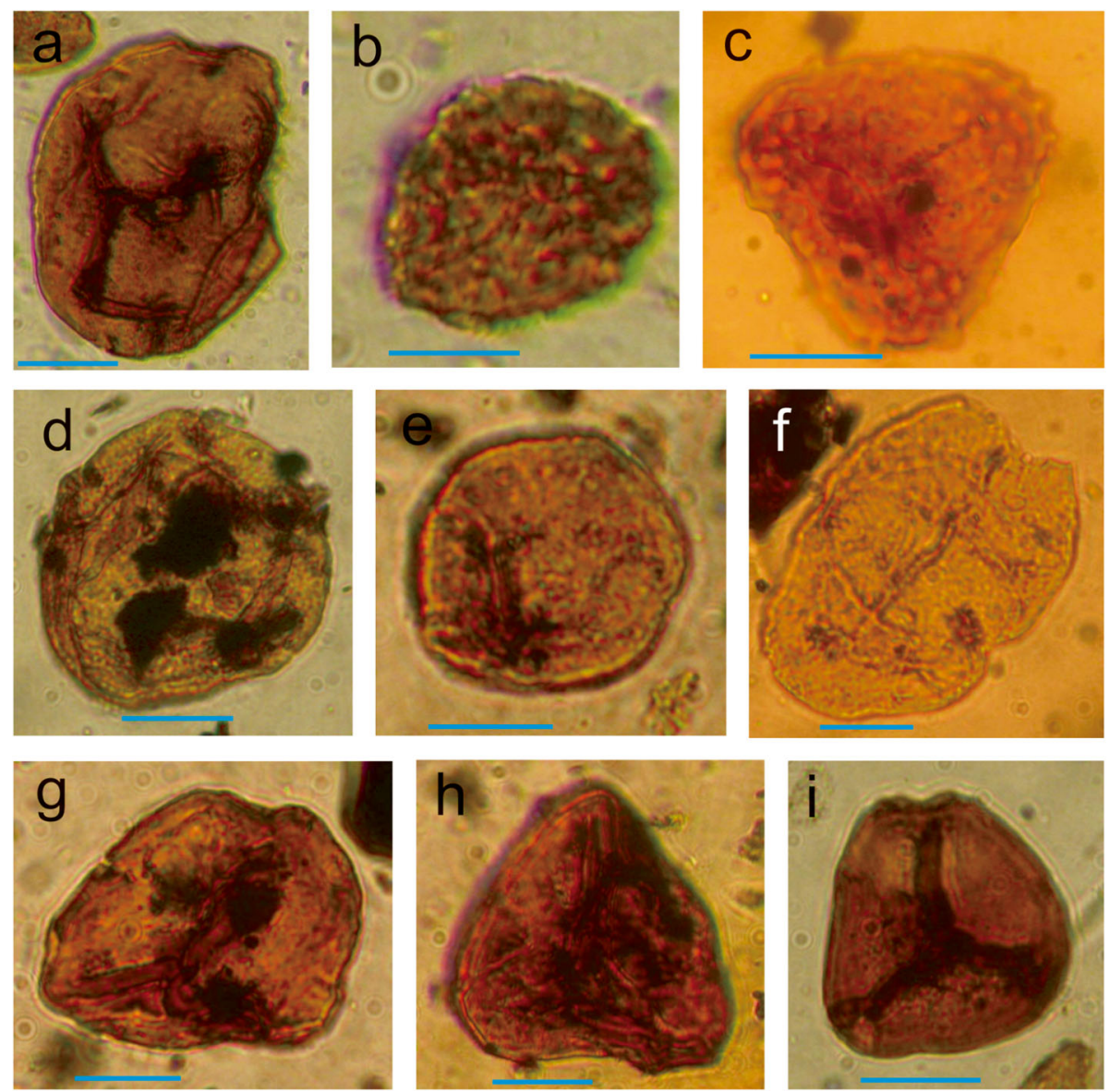

Fig. 5 Photomicrographs of a selection of spore and pollen fossils identified in samples from boreholes XB15 and DB2 in Shandong Province. a Calamospora pedata; b Converrucosisporites minutus; c Converrucosisporites sp.; d Cyclogranisporites microgranus; e Cyclogranisporites pseudozonatus; f Florinites antiquus; $\mathbf{g}$ Gulisporites cerevus; $\mathbf{h}$ Gulisporites curvatus; i Gulisporites laevigatus. Scale bars (in each) $=20 \mu \mathrm{m}$

\section{Discussion}

5.1 The geological age of spores and pollen assemblages In the spores and pollen assemblage established in the upper Taiyuan Formation in western Shandong (Li et al. 2013), pteridophyte spores with main genera and species as Punctatisporites minutus, P. punctatus, Leiotriletes adnatus, and Laevigatosporites perminutus were dominant, and thus the geological age of this assemblage was interpreted as late Cisuralian by $\mathrm{Li}$ et al. (2013). Additionally, the stratigraphically highest conodont belt in the Taiyuan Formation of North China was the Sweetognathus whitei belt, corresponding to the late Cisuralian (Gao et al. 2005; Shen et al. 2019).

The Assemblage I established in this study and the spores and pollen assemblage established by $\mathrm{Li}$ et al. (2013) were both from the Taiyuan Formation of Shandong and contained common genera and species like Laevigatosporites perminutus, Granulatisporites granulatus, and G. minutus; therefore, these two assemblages can be compared, and the geological age of Assemblage I of this study can also be inferred as late Cisuralian.

The Gulisporites cochlearius-Leiotriletes adnatusSinulatisporites sinensis assemblage established in the Shanxi Formation of western Shandong by Tian et al. (2015) and the Assemblage II established in the Shanxi Formation in this study were both characterized by Gulisporites and Sinulatisporites, as well as an abundance of Sinulatisporites. Thus, we adopt the geological age of the assemblage identified by Tian et al. (2015), i.e., early Guadalupian, as the inferred age of Assemblage II of this study.

\subsection{Flora and environmental change}

The original diversity of a fossil flora can be reconstructed by a statistical analysis of spores and pollen (e.g., Pfefferkorn and Thomson 1982; Li et al. 2003; 

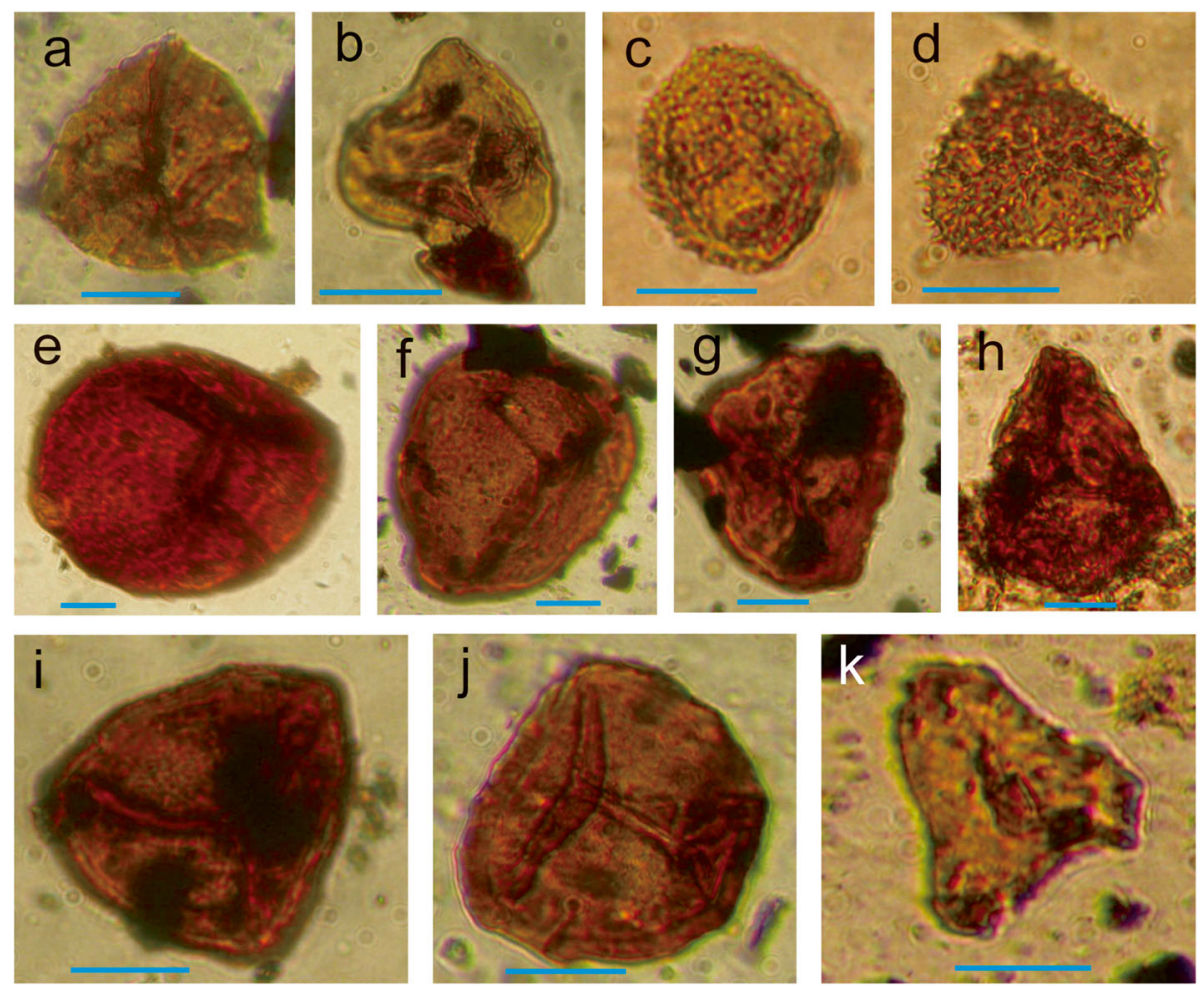

Fig. 6 Photomicrographs of a selection of spore and pollen fossils identified in samples from boreholes XB15 and DB2 in Shandong Province. a Gulisporites sp.; b Leiotriletes tangyiensis; c Lophotriletes cf. communis; d Lophotriletes humilus; e Punctatisporites gigantus; $\mathbf{f}$ Punctatisporites incomptus; g Sinulatisporites of. shanxiensis; h Sinulatisporites of. sinensis; i Stenozonotriletes marginellus; j Stenozonotriletes sp.; $\mathbf{k}$ Triquitrites sp. Scale bars (in each) $=20 \mu \mathrm{m}$

Wang 2010; Barbolini and Bamford 2014). We therefore attempted to establish the affinities of the primary spores and pollen taxa before analyzing vegetation succession and environmental changes, although this work has proved challenging in the past. We constructed Table 5 based on some results of previous studies. This compilation allowed the trends of the flora and environmental changes to be identified more easily.

According to Table 5, the flora of Assemblage I were composed mainly of the filicalean group,

Table 3 Comparison of spores and pollen contents (relative abundance) of Assemblage I from the Permian Taiyuan Formation in Shandong Province, North China

\begin{tabular}{|c|c|c|c|c|c|}
\hline $\begin{array}{l}\text { Location (see Fig. 1b for } \\
\text { reference) }\end{array}$ & $\begin{array}{l}\text { Spores and pollen } \\
\text { assemblage }\end{array}$ & $\begin{array}{l}\text { Relative abundance of } \\
\text { Azonotriletes } \\
(\%)\end{array}$ & $\begin{array}{l}\text { Relative abundance } \\
\text { of Zonotriletes } \\
(\%)\end{array}$ & $\begin{array}{l}\text { Relative abundance } \\
\text { of Monoletes } \\
(\%)\end{array}$ & $\begin{array}{l}\text { Relative abundance of } \\
\text { Gymnosperm pollen } \\
(\%)\end{array}$ \\
\hline $\begin{array}{l}\text { Northern Shandong } \\
\text { Province }\end{array}$ & $\begin{array}{l}\text { Kaipingispora- } \\
\text { Densosporites- } \\
\text { Crassispora }\end{array}$ & 87.1 & 8.5 & $7.0-24.6$ & 9.0 \\
\hline $\begin{array}{l}\text { Feicheng coalfield, } \\
\text { Shandong Province }\end{array}$ & $\begin{array}{l}\text { Thymospra thiessenii- } \\
\text { Densosporites }\end{array}$ & $35.8-60.9$ & 10.0 & 20.0 & 5.0 \\
\hline $\begin{array}{l}\text { Xinwen coalfield, } \\
\text { Shandong Province }\end{array}$ & $\begin{array}{l}\text { Laevigatosporites- } \\
\text { Thymospora }\end{array}$ & 62.6 & 8.6 & 23.0 & 6.2 \\
\hline $\begin{array}{l}\text { Jining coalfield, } \\
\text { Shandong Province }\end{array}$ & $\begin{array}{l}\text { Thymospora } \\
\text { pseudothiessenii- } \\
\text { thiessenii }\end{array}$ & 25.7 & 11.6 & 55.2 & 7.2 \\
\hline $\begin{array}{l}\text { Boreholes XB15 and } \\
\text { DB2 (This study) }\end{array}$ & $\begin{array}{l}\text { Laevigatosporites- } \\
\text { Granulatisporites }\end{array}$ & 73.2 & 3.6 & 21.2 & 2.0 \\
\hline
\end{tabular}

Note: Data of the northern Shandong Province, Feicheng, Xinwen, and Jining coalfields are from Li et al. (2013) 
Table 4 Comparison of spores and pollen contents (relative abundance) of Assemblage II from the Permian Shanxi Formation in Shandong Province, North China

\begin{tabular}{|c|c|c|c|c|c|}
\hline $\begin{array}{l}\text { Location (see Fig. 1b } \\
\text { for reference) }\end{array}$ & Spores and pollen assemblage & $\begin{array}{l}\text { Relative abundance } \\
\text { of Azonotriletes } \\
(\%)\end{array}$ & $\begin{array}{l}\text { Relative abundance } \\
\text { of Zonotriletes } \\
\text { (\%) }\end{array}$ & $\begin{array}{l}\text { Relative abundance } \\
\text { of Monoletes } \\
\text { (\%) }\end{array}$ & $\begin{array}{l}\text { Relative abundance of } \\
\text { Gymnosperm pollen } \\
\text { (\%) }\end{array}$ \\
\hline $\begin{array}{l}\text { Jiyang coalfield, } \\
\text { Shandong Province }\end{array}$ & $\begin{array}{l}\text { Cyclogranisporites- } \\
\text { Granulatisporites- } \\
\text { Laevigatosporites }\end{array}$ & 45.6 & 10.2 & 24.7 & $12.7-30.5$ \\
\hline $\begin{array}{l}\text { Liaocheng coalfield, } \\
\text { Shandong Province }\end{array}$ & $\begin{array}{l}\text { Gulisporites cochlearius- } \\
\text { Sinulatisporites sinensis }\end{array}$ & 54.4 & 19.7 & 17.3 & $1.7-26.6$ \\
\hline $\begin{array}{l}\text { Feicheng coalfield, } \\
\text { Shandong Province }\end{array}$ & $\begin{array}{l}\text { Gulisporites cochlearius- } \\
\text { Sinulatisporites sinensis }\end{array}$ & $57.2-78.4$ & 2.1 & 20.0 & $24.4-38.8$ \\
\hline $\begin{array}{l}\text { Xinwen coalfield, } \\
\text { Shandong Province }\end{array}$ & $\begin{array}{l}\text { Gulisporites cochlearius- } \\
\text { Sinulatisporites sinensis }\end{array}$ & $55.0-68.9$ & 7.0 & 14.0 & 16.4 \\
\hline $\begin{array}{l}\text { Boreholes XB15 and } \\
\text { DB2 (This study) }\end{array}$ & Gulisporites-Sinulatisporites & 59.8 & 13.6 & 20.7 & 5.9 \\
\hline
\end{tabular}

Note: Data of Jiyang, Liaocheng, Feicheng, and Xinwen coalfields are from Zhao et al. (2006)

marattialean ferns, and gymnospermous Pteridosperms. The Cordaitales began to expand in importance with a synchronous decline of the isoetalean lycopsids, which is a typical pattern for the Cathaysian flora during the late Cisuralian. The composition of the Assemblage I revealed that the palaeoclimate was warm, humid, and seasonally dry or semi-arid. There might be an alternation of warm and humid conditions with drier conditions. The flora of Assemblage II showed a predominance of Filicales and Pteridosperms, and a further development of Sphenophyllales and Cordaitales, especially Sinulatisporites, which speculated that the plant produced Sinulatisporites was a fern or seed fern that preferred a wet and hot climate (Zhang et al. 2005). A warm and humid climate was still dominant during early Guadalupian time. However, the genus Denosporites, which represents Lycopsida, appeared sporadically, reflecting a further decline of isoetalean lycopsids in the Assemblage II. The increase in abundance of Florinites likely indicated a change to semi-arid climatic conditions.

In addition, from field observations, there is no obvious stratigraphic hiatus and lithological change between the top of the Taiyuan Formation and the bottom of the Shanxi Formation in the study area. However, from the flora represented by spore and pollen assemblages, we can distinguish the stratigraphic boundary of the Taiyuan and Shanxi formations. The flora belonging to the Shanxi Formation (Assemblage II of this study) can be distinguished from those of the Taiyuan Formation (Assemblage I of this study) by the sudden decline of Lepidodendrales and the emergence of new elements of true ferns and seed ferns.

\subsection{A preliminary comparison between Cathaysian and Euramerican floras}

The above analysis provides evidence that the Cathaysian flora consisted of plants that preferred a humid and warm (tropical) climate, including Lycopsida, Pteridopsida, and Cordaitales. However, the Euramerican habitat was characterized by a dry climate during the Cisuralian (DiMichele and Aronson 1992; Sun et al. 2000; DiMichele et al. 2001, 2009), where the plants requiring humid and warm conditions disappeared.

In summary, through a preliminary climatic comparison analysis, the principal outcome of this study is that plants which grew vigorously as the Cathaysian flora during the Early-Middle Permian Period were mainly developed in Late Pennsylvanian time in Euramerica. Further study will help to test and refine these results towards a better understanding and clearer comparison analysis.

\section{Conclusions}

1) This study recognized two assemblages, the Laevigatosporites-Granulatisporites assemblage (Assemblage I) and the GulisporitesSinulatisporites assemblage (Assemblage II), from an Early-Middle Permian sequence (Taiyuan and Shanxi formations) of Shandong Province, eastern North China, and established the affinities of spores and pollen taxa of the two assemblages.

2) The two assemblages had typical characteristics of the Cathaysian flora, which is widely distributed in North China during the Late Paleozoic Era. Abundant Marattiales were found in Assemblage I. The sudden decline of 
Table 5 Affinities of the main spores and pollen taxa in the identified Laevigatosporites-Granulatisporites and GulisporitesSinulatisporites assemblages in the present study

\begin{tabular}{|c|c|c|c|c|c|}
\hline Genera & Affinities & Literature & Assemblage & Formation & $\begin{array}{l}\text { Palaeoclimate } \\
\text { type }\end{array}$ \\
\hline Leiotriletes & Filicinae, leicheniaceae, Pteridosperms & Su et al. 2007 & $\begin{array}{l}\text { Assemblage } \\
\text { । }\end{array}$ & Taiyuan & $\begin{array}{l}\text { Warm and } \\
\text { humid }\end{array}$ \\
\hline Punctatisporites & Filicales, Marattiales, Gleicheniaceae & Tian et al. 2015 & $\begin{array}{l}\text { Assemblage } \\
\text { I }\end{array}$ & Taiyuan & $\begin{array}{l}\text { Warm and } \\
\text { humid }\end{array}$ \\
\hline Granulatisporites & Filicinae & Su et al. 2007 & $\begin{array}{l}\text { Assemblage } \\
\text { । }\end{array}$ & Taiyuan & $\begin{array}{l}\text { Warm and } \\
\text { humid }\end{array}$ \\
\hline Calamospora & Calamitales, Sphenopsida & Ouyang et al. 2017 & $\begin{array}{l}\text { Assemblage } \\
\text { । }\end{array}$ & Taiyuan & Seasonally dry \\
\hline Verrucosisporites & Marattiales, Pteridosperms & Su et al. 2007; Ouyang et al. 2017 & $\begin{array}{l}\text { Assemblage } \\
\text { I }\end{array}$ & Taiyuan & $\begin{array}{l}\text { Warm and } \\
\text { humid }\end{array}$ \\
\hline Punctatosporites & Marattiales & Ouyang et al. 2017 & $\begin{array}{l}\text { Assemblage } \\
\text { I }\end{array}$ & Taiyuan & $\begin{array}{l}\text { Warm and } \\
\text { humid }\end{array}$ \\
\hline Laevigatosporites & $\begin{array}{l}\text { Sphenopsida (large size), Filicales (small } \\
\text { size) }\end{array}$ & $\begin{array}{l}\text { Balme 1995; Su et al. 2007; Ouyang et al. } \\
2017\end{array}$ & $\begin{array}{l}\text { Assemblage } \\
\text { । }\end{array}$ & Taiyuan & Semi-arid \\
\hline Thymospora & Marattiales & Ouyang et al. 2017 & $\begin{array}{l}\text { Assemblage } \\
\text { I }\end{array}$ & Taiyuan & $\begin{array}{l}\text { Warm and } \\
\text { humid }\end{array}$ \\
\hline Convolutispora & Marattiales & Su et al. 2007 & $\begin{array}{l}\text { Assemblage } \\
\text { I }\end{array}$ & Taiyuan & $\begin{array}{l}\text { Warm and } \\
\text { humid }\end{array}$ \\
\hline Lycospora & Lepidodendrales & Ouyang et al. 2017 & $\begin{array}{l}\text { Assemblage } \\
\text { I }\end{array}$ & Taiyuan & $\begin{array}{l}\text { Warm and } \\
\text { humid }\end{array}$ \\
\hline Gulisporites & Filicinae & Su et al. 2007 & $\begin{array}{l}\text { Assemblage } \\
\|\end{array}$ & Shanxi & $\begin{array}{l}\text { Warm and } \\
\text { humid }\end{array}$ \\
\hline Sinulatisporites & Filicinae, Pteridosperms & Zhang et al. 2005 & $\begin{array}{l}\text { Assemblage } \\
\|\end{array}$ & Shanxi & $\begin{array}{l}\text { Warm and } \\
\text { humid }\end{array}$ \\
\hline Crassispora & Lycopsida & Ouyang et al. 2017 & $\begin{array}{l}\text { Assemblage } \\
\|\end{array}$ & Shanxi & Semi-arid \\
\hline Densosporites & Lycopsida & Wang et al. 2003 & $\begin{array}{l}\text { Assemblage } \\
\|\end{array}$ & Shanxi & Semi-arid \\
\hline Lophotriletes & Filicinae & Su et al. 2007 & $\begin{array}{l}\text { Assemblage } \\
\|\end{array}$ & Shanxi & $\begin{array}{l}\text { Warm and } \\
\text { humid }\end{array}$ \\
\hline Cyclogranisporites & Filicales, Pteridosperms & Ouyang et al. 2017 & $\begin{array}{l}\text { Assemblage } \\
\|\end{array}$ & Shanxi & $\begin{array}{l}\text { Warm and } \\
\text { humid }\end{array}$ \\
\hline Triquitrites & Lycopsida & Su et al. 2007 & $\begin{array}{l}\text { Assemblage } \\
\|\end{array}$ & Shanxi & Semi-arid \\
\hline Stenozonotriletes & Lycopsida & Su et al. 2007 & $\begin{array}{l}\text { Assemblage } \\
\|\end{array}$ & Shanxi & Semi-arid \\
\hline Florinites & Cordaitales & Zhao et al. 2006 & $\begin{array}{l}\text { Assemblage } \\
\|\end{array}$ & Shanxi & Semi-arid \\
\hline
\end{tabular}

Lepidodendrales marks the distinction of Assemblage II.

3) Similar components, such as pteridophytes, existed between Euramerican and Cathaysian floras. Moreover, pteridophytes of the Euramerican flora representing a warm and humid climate were mainly developed in the Late Pennsylvanian, while pteridophytes of the Cathaysian flora lasted until the Early-Middle Permian.

\section{Acknowledgements}

The authors thank Prof. W.A. DiMichele from Department of Paleobiology, National Museum of Natural History, Smithsonian Institution, Washington,
USA for his suggestions on an earlier version of this paper. Thanks are also given to Prof. Zeng-Zhao Feng, Prof. Stephen Kershaw, other anonymous reviewers and editors for their very helpful comments.

\section{Authors' contributions}

TTY was the main contributor of the manuscript; SJL was the director, writer and appraiser of experimental results; XYZ was in charge of the drawing making and data analysis; XLZ was in charge of the experimental analysis and data arrangement. All authors read and approved the final manuscript.

\section{Funding}

This study was supported by the Open Foundation for the Modern Key Laboratory of Paleontology and Stratigraphy, Nanjing Institute of Geology and Paleontology, Chinese Academy of Sciences (Grant No. 123104). 


\section{Availability of data and materials}

The datasets generated and/or analysed during the current study are available in the [College of Earth Science and Engineering, Shandong University of Science and Technology] Repository.

\section{Competing interests}

The authors declare that they have no competing interests.

\section{Author details}

'College of Earth Science and Engineering, Shandong University of Science and Technology, Qingdao 266590, Shandong Province, China. ${ }^{2}$ China Chemical Geology and Mine Bureau Shandong Geological Prospecting Institute, Ji'nan 250013, Shandong Province, China.

\section{Received: 11 December 2019 Accepted: 2 August 2020}

\section{Published online: 19 August 2020}

\section{References}

Alpern, B. 1956. Succinct description of the principal genera and species of pollen and spores found in the coals of central and eastern France. In Entred'Etudes et Recherches des Charbonnages de France 56-9-052, 233 pls.

Alpern, B. 1958. Description de Quelques Microspores du Permo-carbonifere Francais. Review Micropaleontology 1: 75-86.

Balme, B.E. 1995. Fossil in situ spores and pollen grains: An annotated catalogue. Review of Palaeobotany and Palynology 87: 81-323.

Barbolini, N., and M.K. Bamford. 2014. Palynology of an early Permian coal seam from the Karoo Supergroup of Botswana. Journal of African Earth Sciences 100: 136-144.

Bharadwaj, D.C. 1954. Einige neue Sporengattungen des Saarkarbons. Neues Jahrbuch fur Mineralogie. Geologie und Palaontologie 11: 512-525.

Bharadwaj, D.C. 1957. The palynological investigations of the Saar coals (part 1-Morphography of Sporae dispersae). Palaeontographica 101B: $73-125$.

Cheng, Y.Q. 2000. China stratigraphy of Permian, 149. Beijing: Geological Publishing House (in Chinese).

Cleal, C.J., and Z.Q. Wang. 2002. A new and diverse plant fossil assemblage from the upper Westphalian Benxi formation, Shanxi, China, and its palaeofloristic significance. Geological Magazine 139: 107-130.

DiMichele, W.A., and R.B. Aronson. 1992. The Pennsylvanian-Permian vegetational transition: A terrestrial analogue to the onshore-offshore hypothesis. Evolution 46: 807-824.

DiMichele, W.A., C.V. Looy, and D.S. Chaney. 2011. A new genus of gigantopterid from the middle Permian of the United States and China and its relevance to the gigantopterid concept. International Journal of Plant Sciences 172: 107-119.

DiMichele, W.A., I.P. Montanez, C.J. Poulsen, and N.J. Tabor. 2009. Climate and vegetational regime shifts in the late Paleozoic ice age earth. Geobiology 7: 200-226.

DiMichele, W.A., H.W. Pfefferkorn, and R.A. Gastaldo. 2001. Response of late carboniferous and early Permian plant communities to climate change. Annual Review of Earth and Planetary Sciences 29: 461-487.

DiMichele, W.A., T.L. Phillips, and H.W. Pfefferkorn. 2006. Paleoecology of late Palaeozoic pteridosperms from tropical Euramerica. Journal of the Torrey Botanical Society 133: 83-118.

Falcon-Lang, H.J., and A.C. Scott. 2000. Upland ecology of some late carboniferous cordaitalean trees from Nova Scotia and England. Palaeogeography Palaeoclimatology Palaeoecology 156: 225-242.

Felix, C.J., and P.P. Burbridge. 1967. Palynology of the springer formation of southern Oklahoma, USA. Palaeontology 10: 349-435 14 pls.

Gao, L.D. 1984. Carboniferous and Permian spores and pollen. In Paleontological Atlas of North China, v. 3, Micropalaeontologica, ed. Tianjin Institute of Geology and Mineral Resource. (Ed.), 440. Beijing: Geological Publishing House (in Chinese).

Gao, L.F., H. Ding, and X.Q. Wan. 2005. Taxonomic revision of conodont Sweetognathus species in the uppermost Taiyuan formation, Yuhuai Basin and its significance. Acta Micropalaeontologica Sinica 22 (4): 370382 (in Chinese with English abstract).
Gastaldo, R.A. 1987. Confirmation of carboniferous clastic swamp communities. Nature 326: 869-871.

Gastaldo, R.A., W.A. DiMichele, and H.W. Pfefferkorn. 1996. Out of the icehouse into the greenhouse: A late Paleozoic analog for modern global vegetational change. GSA Today 6: 1-7.

Hacquebard, P.A. 1957. Plant spores in coal from the Horton group (Mississippian) of Nova Scotia. Micropaleontology 3: 301-324 3pls.

Halle, T.G. 1935. On the distribution of the late Palaeozoic flora in Asia. Geografiska Annaler 17: 106-111.

Hilton, J., and C.J. Cleal. 2007. The relationship between Euramerican and Cathaysian tropical floras in the late Palaeozoic: Palaeobiogeographical and palaeogeographical implications. Earth-Science Reviews 85: 85-116.

Hoffmeister, W.S., F.L. Staplin, and R.E. Malloy. 1955. Mississippian plant spores from the Hardinsburg formation of Illinois and Kentucky. Journal of Paleontology 29: 372-399.

Hou, J.-P., and Z. Wang. 1986. Late Permian sporo-pollen assemblages. In Permian and Triassic strata and fossil assemblages in the Dalongkou area of Jimsar, Xinjiang, Geological Memoir Series, 70-110. Beijing: Geological Publishing House (in Chinese with English summary).

Ibrahim, A.C. 1933. Sporenformen des Aegirhorizonts des Ruhr-Reviers, 47. Wurzburg: Berlin Dissertation privately publishing. 8 pls.

Imgrund, R. 1952. The Sporites of the Kaiping Basin, 1-96. Aachen: RheinlandWestfalen Tech. Hochschule PhD Dissertation.

Imgrund, R. 1960. Sporae dispersae des Kaipingbeckens,ihre palaontologische und stratigraphische beareitung im Hinblick auf eine Parallelisierung mit dem Ruhrkarbon und dem Pennsylvanian von Illinois. Geologisches Jahruch 77: 143-204.

Jiang, H.C., M.Z. Wang, X.Q. Zhang, and Z.X. Li. 2002. Study on late Paleozoic sporopollen assemblages in east part of Jining coalfield, Shandong province. Chinese Journal of Geology 37 (1): 47-61 (in Chinese with English abstract).

Kosanke, R.M. 1950. Pennsylvanian spores of Illinois and their use in correlation. Illinois Geological Survey Bulletin 74: 1-128.

Li, S.J., M.Z. Wang, D.S. Zheng, and X.L. Zhao. 2003. Recovery of climate of Paleogene in Jiyang depression of Shandong. Journal of Shandong University of Science and Technology (Natural Science) 22 (3): 6-9 (in Chinese with English abstract).

Li, S.J., X.L. Zhao, T.T. Yin, L.Y. Yuan, M. He, F.L. Xu, R. Chen, and P.P. Huang 2013. The characteristics of early to middle Permian sporopollen assemblages in Pengzhuang, Shandong Province. Acta Geologica Sinica 87 (12): 1819-1825 (in Chinese with English abstract).

Li, X.X. 1997. The origin, evolution and distribution of the Cathaysian Flora in East Asia. Acta Palaeontologica Sinica 36 (4): 411-422 (in Chinese with English abstract).

Lü, D.W. 2015. Discussion on micro-characteristics of transgressive event deposition and its coal-forming mechanism in the late Paleozoic epicontinental sea basin of North China. Acta Sedimentologica Sinica 33 (4): 633-640 (in Chinese with English abstract).

Mei, S.L., C.M. Henderson, and C.Q. Cao. 2004. Conodont sample-population approach to defining the base of the Changhsingian stage, Lopingian series, upper Permian. The palynology and micropalaeontology of boundaries. The Geological Society of London, Special Publication 230: 105-121.

Meyen, S.V. 1997. Permian conifers of Western Angaraland. Review of Palaeobotany and Palynology 96: 351-447.

Naugolnykh, S.V. 2002. Paracalamitina striata - A newly reconstructed equisetophyte from the Permian of Angaraland. Journal of Paleontology 76 (2): 377-385.

Naumova, S.N. 1953. Spore-Pollen assemblages of the Upper Devonian of the Russian Platform and their stratigraphic significance. Transactions of the Institute of Geological Sciences, Academy of Science, SSSR 143 (Geol. Ser.60): 1-204 (in Russian).

Ouyang, S. 1962. The microspore assemblage from the Longtan series of Changxing, Chekiang. Acta Palaeontologica Sinica 10 (1): 76-119 (in Chinese with English abstract).

Ouyang, S. 1986. Palynology of upper Permian and lower Triassic of Fuyuan district, eastern Yunnan, China. Palaeontologia Sinica, NSA 9: 1-122 (in Chinese). 
Ouyang, S., and J.P. Hou. 1999. On characteristics of the Cathaysian palynoflora. Acta Palaeontologica Sinica 38 (3): 261-281 (in Chinese with English abstract).

Ouyang, S., L.C. Lu, H.C. Zhu, and F. Liu. 2017. The late Paleozoic spores and pollen of China, 36-613. Hefei: Press of University of Science and Technology of China (in Chinese).

Peppers, R.A. 1996. Palynological correlation of major Pennsylvanian (middle and upper carboniferous) chronostratigraphic boundaries in the Illinois and other coal basins. Geological Society of America Memoirs 188: 1-111.

Pfefferkorn, H.W., and M.C. Thomson. 1982. Changes in dominance patterns in upper carboniferous plant-fossil assemblages. Geology 10: 641-644.

Pfefferkorn, H.W., and J. Wang. 2007. Early Permian coal-forming floras preserved as compressions from the Wuda District (Inner Mongolia, China). International Journal of Coal Geology 69: 90-102.

Phillips, T.L., and W.A. DiMichele. 1992. Comparative ecology and life-history biology of arborescent lycopsids in late carboniferous swamps of Euramerica. Annals of the Missouri Botanical Garden 79: 560-588.

Potonié, R., and G. Kremp. 1954. Die Gattungen der palaozoischen Sporae dispersae und ihre Stratigraphie. Geologisches Jahruch 69: 111-194.

Potonié, R., and G. Kremp. 1955. Die sporae dispersae des Ruhrkarbons ihr Morphographie und Stratigraphie mit Ausblicken auf Arten anderer Gebiete und Zeitabschnitte. Palaeontographica 98 (B): 1-136.

Potonié, R., and G. Kremp. 1956. Die sporae dispersae des Ruhrkarbons ihre morphographie und Stratigraphie mit Ausblicken auf Arten anderer Gebiete und Zeitabschnitte. Palaeontographica 99 (B): 85-191.

Schopf, J.M., L.R. Wilson, and R. Bentall. 1944. An annotated synopsis of Palaeozoic fossil spores and the definition of generic groups: Illinois state geological survey. Report of Investigations 92: 1-72.

Scott, A.C. 1974. The earliest conifer. Nature 251: 707-708.

Shen, S.Z., and S.L. Mei. 2010. Lopingian (late Permian) high-resolution conodont biostratigraphy in Iran with comparison to South China zonation. Geological Journal 45: 135-161.

Shen, S.Z., Y. Wang, and Y.G. Jin. 2005. Progress report on the global stratotype sections and points (GSSP) of the Permian in system. Journal of Stratigraphy 29 (2): 138-146 (in Chinese with English abstract).

Shen, S.Z., H. Zhang, Y.C. Zhang, D.X. Yuan, B. Chen, W.H. He, L. Mu, W. Lin, W.Q. Wang, J. Chen, Q. Wu, C.Q. Cao, Y. Wang, and X.D. Wang. 2019. Permian integrative stratigraphy and timescale of China. Science China Earth Sciences 62: 154-188.

Shi, G.R., and Z.Q. Chen. 2003. Global review of Permian Tyloplecta Muirwood and Cooper, 1960 (Brachiopoda): Morphology, palaeobiogeographical and palaeogeographical implications. Gondwana Research 6: 777-790.

Smith, A.H.V., and M.A. Butterworth. 1967. Miospores in coal seams of the Great Britain. Special Papers in Palaeontology 1: 1-321 29pls.

Song, X.S., K.F. Wang, M.Z. Wang, and Q. Jia. 2009. Permian sporo-pollen assemblages of the Echeng town coalfield, Liaocheng, Shandong Province. Acta Micropalaeontologica Sinica 26 (3): 271-282 (in Chinese with English abstract).

Song, X.S., X.Q. Zhang, and M.Z. Wang. 2005. The Foraminiferal fauna and the carboniferous-Permian boundary in the Taiyuan formation of the Xinwen coalfield, Shandong province. Acta Micropalaeontologica Sinica 22 (1): 47-58 (in Chinese with English abstract).

Spencer, A.R., S. Wang, M.T. Dunn, and J. Hilton. 2013. Species of the medullosan ovule Stephanospermum from the Lopingian (late Permian) floras of China. Journal of Asian Earth Sciences 76: 59-69.

Su, W., X.L. Huang, M.Z. Wang, and X.Q. Zhang. 2007. Carboniferous-Permian Palynoflora and Paleoclimate of the Tengxian coalfield, Shandong. Acta Micropalaeontologica Sinica 24 (1): 98-104 (in Chinese with English abstract).

Sun, K.Q. 1996. Origin of the Cathaysia flora in Asia. Palaeobotanist 43: 5962.

Sun, K.Q. 1997. Characteristics of the evolution and distribution of the global carboniferous and Permian floras. Earth Science Frontiers 4: 129138 (in Chinese with English abstract).

Sun, K.Q. 2001. Carboniferous and Permian floras in China. Chinese Bulletin of Botany 18 (6): 691-706 (in Chinese with English abstract).
Sun, K.Q. 2006. The Cathaysia Flora and the mixed late Permian CathaysianAngaran floras in East Asia. Journal of Integrative Plant Biology 48: $381-$ 389

Sun, K.Q., X.Y. Shi, and J.Z. Cui. 2000. Phytogeographical provinces of the carboniferous and Permian in the world. Chinese Bulletin of Botany 17 (3): 193-203 (in Chinese with English abstract).

Tian, B.L., S.J. Wang, Y.T. Guo, G.R. Chen, and H. Zhao. 1996. Flora of Palaeozoic coal balls of China. Palaeobotanist 45: 247-254.

Tian, B.L., S.J. Wang, C.S. Li, and G.R. Chen. 2000. An approach on the origin Centre and the mechanics of evolution and extinction of the late Palaeozoic Cathaysian flora. Chinese Bulletin of Botany 17: 21-33 (in Chinese with English abstract).

Tian, C.L., S.J. Li, F.L. Xu, and X.L. Zhao. 2015. Carboniferous and Permian palynological assemblages and the coal forming environment in Pengzhuang coal mine of Shandong Province. Coal Geology \& Exploration 43 (6): 12-22 (in Chinese with English abstract).

Vega, J.C., and S. Archangelsky. 1997. The first Gondwana carboniferous compound cupules and associated seeds. A preliminary note. Review of Palaeobotany and Palynology 99: 55-59.

Wang, J. 2010. Late Paleozoic macrofloral assemblages from Weibei coalfield, with reference to vegetational change through the late Paleozoic ice-age in the North China block. International Journal of Coal Geology 83: 292-317.

Wang, J., and H.W. Pfefferkorn. 2013. The carboniferous-Permian transition on the North China microcontinent-oceanic climate in the tropics. International Journal of Coal Geology 119: 106-113.

Wang, M.Z., X.Q. Zhang, and X.L. Zhao. 2003. Permian spore-pollen assemblage of early and middle period of early Permian in Western Shandong. Journal of Shandong University of Science and Technology 22: 1-6.

Winston, R.B. 1983. A late Pennsylvanian upland flora in Kansas: Systematics and environmental implications. Review of Palaeobotany and Palynology 40: 5-31.

Yin, T.T., S.J. Li, and X.L. Zhao. 2016. Sequence stratigraphic and characteristics of carboniferous and Permian coal accumulation in Pengzhuang area of Shandong province. Land and Resources in Shandong 32 (12): 25-29 (in Chinese with English abstract).

Zhang, S.G., Y.B. Zhang, and H.J. Yan. 2009. A brief introduction to the "international stratigraphic chart" (2008). Journal of Stratigraphy 33 (1): 1-10 (in Chinese with English abstract).

Zhang, X.Q., M.Z. Wang, and X.L. Zhao. 2005. Temporal-spatial distribution of Sinulatisporites in North China and its stratigraphic significance. Acta Palaeontologica Sinica 44 (2): 306-313 (in Chinese with English abstract).

Zhao, X.L., S.J. Li, and X.Q. Zhang. 2006. Permian sporo-pollen assemblages of the Jiyang depression, Shandong province. Acta Micropalaeontologica Sinica 23 (2): 165-174 (in Chinese with English abstract).

Zhou, H.Y. 1980. The sporopollen assemblage from the Upper Paleozoic in northern Shandong Province. In Symposium on Stratigraphy and Palaeontology oil and gas bearing areas in China (I), 1-17. Beijing: Petroleum Industry Press (in Chinese).

Zhu, Y.Y., J.S. Zhang, Q. Jia, X.Q. Zhang, and M.Z. Wang. 2005. Study on the Fusulinida fauna and the carboniferous-Permian boundary in the Taiyuan formation from the Yanzhou coalfield, Shandong Province. Acta Micropalaeontologica Sinica 22 (4): 400-411 (in Chinese with English abstract).

\section{Publisher's Note}

Springer Nature remains neutral with regard to jurisdictional claims in published maps and institutional affiliations. 